\title{
Pricing and Marketing the e-Databases and Deprivation of Users: A Case Study of Delhi State of India
}

\author{
Professor (Dr.) Haridwar Singh Rai \\ Mangalmay Institute of Management and Technology, Greater Noida \\ P1-104, Golf Link-I, Ansal Housing, Greater Noida, U.P., India \\ Tel: 91-0120-2932269, 9971270064(M)Ｅ-mail: hridwar@gmail.com
}

Dr. Asit Bandyopadhayay (Corresponding author)

Jaypee Business School, JIIT University

A-10, Sector-62, Noida, India

Tel: 91-120-2594471, 9999998578(M)Ｅ-mail:asitb.76@gmail.com

\begin{abstract}
Worldly knowledge system can be termed as an integration of Knowledge economy, information technology, library system as a knowledge facilitator, and e-databases in the epoch of modern globalization. Users across the globe perceived it as a commodity and are paying the price of e-databases. Users and knowledge facilitation centers, libraries and information centers are spending substantial part of their proposed expenditure in order to purchase information products in terms of e-databases globally. Global information industry has touched \$381billion in 2007. In India, except National Informatics Centre (NIC), rests of the e-database players are private and majority of them are MNCs and monopolist competitive market's leaders. The State of Delhi has become a reputed e-database market in India and its players are globally aligned and locally well versed with governments and most of them are cropping government resources for their promotion of marketing. Whether they are really a promoter of knowledge development oriented activities or profit maximization agencies only? Is increasing subscription rate of e-databases becoming a threatening issue for users and libraries and information centers and their establishments? Is nature of market and marketing of e-databases pricing models benefiting the consumers/users/Libraries and Information Professionals (LIPs)? How will the increasing subscription of databases be precipitated in term of development of knowledge economy a, users, libraries and information centers in the State of Delhi in near future? How should users and LIPs react? This paper is a humble effort to deal with these pertinent questions.
\end{abstract}

Keywords: E-databases, Library Information Personals (LIPs), Pricing, Market Structure 


\section{Introduction}

In India, the year 1991 is known as the break-even year in terms of transformation that took place from bipolar world to unilateral globe, i.e., the emergence of globalization. Globalization came into existence with great source of the world linkage and that is introduced as the epoch of information technology. Now information technology has been evolving as source of power for individuals and profit maximization tools and techniques for business organizations locally as well as globally.

The year 1991 also has provided avenues for competitive market economy and ensured efficient uses of human as well as natural resources where information technology plays a vital role. Now, worldly knowledge system is getting more and more importance ever before. Facilitation avenues of Knowledge like libraries and information centre are becoming digitized and users also are getting enlightened with a usage of e-databases within the given limited time frame.

Now the state of Delhi' twin cities-New Delhi and Delhi is a high-tech city in the Indian union. The numbers of users are increasing day by day. NIC, e-databases based Information Centre of Government of India is the major source of e-databases for private consortia and MNCs in the State of Delhi. But their aim is of profit maximization only. Users as well as Library Information Personals (LIPs) are becoming worried with hyper-rising of subscriptions of e-databases since November-December 2005. In such a situation this paper is assigned to study facts and figures related to rising subscription rate of e-databases and its effects upon users in particular and LIPS in general.

This paper is divided into 4 parts. Part I Deal with nature of market structure, Part II: Varieties of E-Databases and Users, Part III: E-Databases Prices in the State of Delhi Part IV: Findings.

\section{Part I}

\section{Nature of Market Structure}

Since the revival of capitalism and destruction of socialist state of USSR, and transition into several independent Nations, Russia came into existence in December 1990 and since then era of globalization started. Central Government introduced Liberalization, Privatization and Globalization (LPG) in Indian economy. Mixed economy pattern of economic development was disapproved, and market oriented economic development got approved by Indian Government on July1991. Wide foundation of competitive market was laid and it started facilitation of liberal economic principles of market development. The various types of market structures prevail in developing countries like India are perfect competition, monopoly, oligopoly, monopolistic competitive markets, and so on.

Under the perfectly competitive market, there are large number of sellers and large number of buyers. They interact with each other in order to purchasing and selling homogenous goods on the given price. They cannot influence the market price either one. Food grain markets and super markets both are the best example of perfect competitive market. In monopoly 
market there is a single firm which exercises power to influence price and the firm is known as a price maker firm instead of price taker (since firms are price taker in perfect competitive market). Oligopoly market structure entertains a few sellers of a commodity.

A monopolist entertains power of price making, and it is defined as monopoly power. Monopoly is measured with a help of Lerner Index. Economist A.P. Lerner devised such an index to measure the degree of Monopoly power which has come to be known as the Lerner Index. This index is denoted by $\mu$.

$\mu=(\mathrm{P}-\mathrm{MC}) / \mathrm{P}$

Where $\mathrm{P}=$ price of firm's product, $\mathrm{MC}=$ Firm's marginal cost.

We know that MC=MR, (Where MR= Marginal Revenue) and

$\mathrm{MR}=\mathrm{P}(1-1 / \mathrm{e}) \quad($ where $\mathrm{e}$ is the price elasticity of demand $)$.

$\mu=(\mathrm{P}-\mathrm{MC}) / \mathrm{P}$

$\mu=(\mathrm{P}-\mathrm{MR}) / \mathrm{P}=1-(\mathrm{MR} / \mathrm{P})$

$\operatorname{But}(\mathrm{MR} / \mathrm{P})=(1-1 / \mathrm{e})$

$\mu=1-(1-1 / e)$

$\mu=1 / \mathrm{e}$

Thus, the monopoly power is inversely related to elasticity of demand for its product. The lower elastic of the demand for its product, the greater would be its monopoly power, and vice versa. Since elasticity of demand depends on the number and closeness of the substitutes available for a product.

Essential goods and services like life saving medicines, petroleum, cooking gas, railways enjoy high degree of monopoly power because the demand for these products is highly inelastic.

In a pure monopoly price will generally be greater than marginal cost and that the firm is able to generate super normal profit in long run. In perfect competitive industry price is determined where marginal cost $(\mathrm{MC})=$ average cost $(\mathrm{AC})$. In such a case consumer surplus is equal to $\Delta \mathrm{P}_{\mathrm{c}} \mathrm{DA}$ (from fig. no.1), but it is reduced to $\Delta \mathrm{A} \mathrm{P}_{\mathrm{m}} \mathrm{B}$. In monopoly market consumer surplus accrued in perfect competition is divided into three parts: a) consumer surplus, b) dead weight loss to society (since area $\triangle \mathrm{BCD}$ is equal to dead weight loss) and c) income transfer $\square \mathrm{P}_{\mathrm{m}} \mathrm{P}_{\mathrm{c}} \mathrm{CB}$ to the monopolist firm in the monopolist market ( fig. no.1), and it is recognized as a profit of monopolist. Thus, a monopolist snatches consumer surplus and brands it his / her own profit, as well as destroy the social welfare of the society (since area of $\triangle \mathrm{BCD}$ becomes vulnerable in monopolist market). 


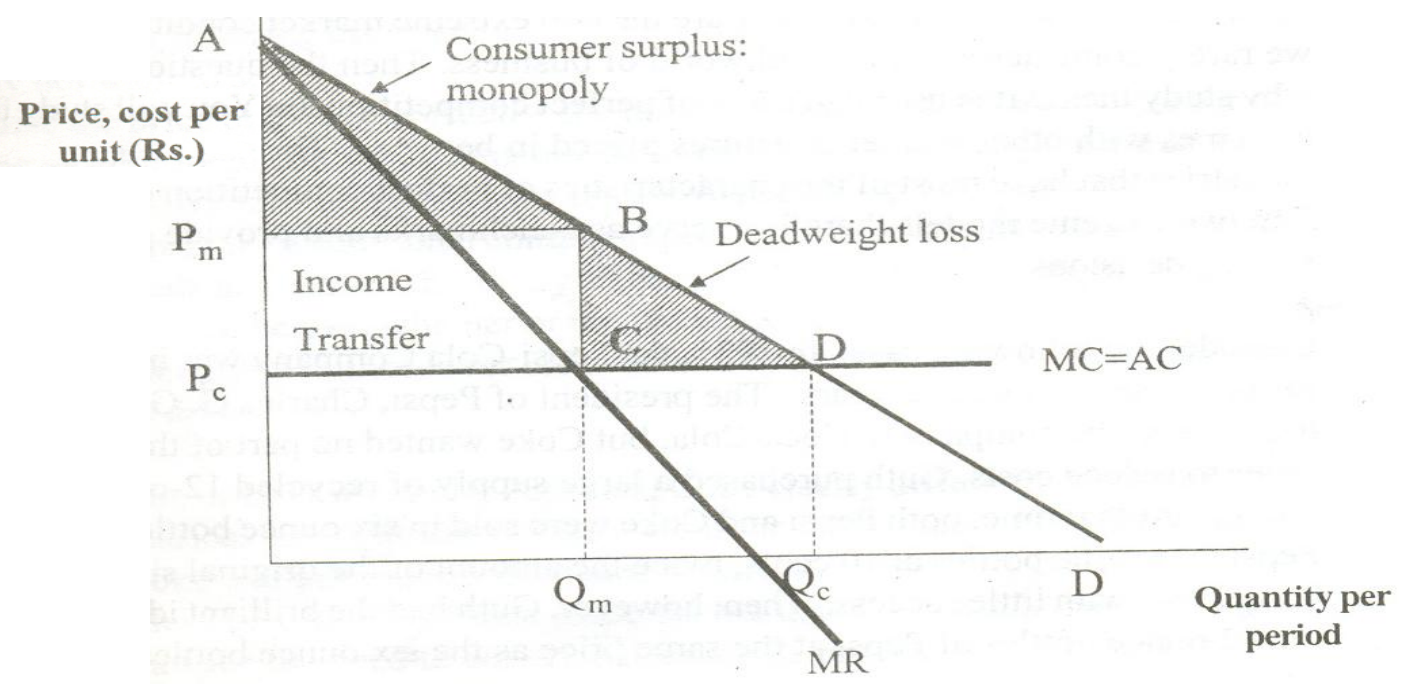

Figure No. 1: Evaluation of monopoly

(Source: Fig. no. 12.4: Evaluation of monopoly, page no. 33, Pricing Decisions, Block no.4, MS-9, Distance Education Study Material, Indira Gandhi National Open University, India.)

In order to protect the social welfare status governments introduced antitrust policy. The instruments under this policy prevent the monopolist from exercising monopoly power. The initial legislation in the US was Sherman Antitrust Act 1890. Any attempt to indulge in monopolistic and unfair trade practices, such as price fixing, full-line forcing, etc., pulled up. Behavior of the firm is continuously monitored by the antitrust authorities. In US, Standard Oil was broken up in 1911 and the Bell System was broken up in 1984 as measures to increase the degree of competition.

India also has been exercised the antitrust policy from 1969. The monopolies and Restrictive Trade Practices Act, 1969 (MRTP Act), was formulated essentially to discourage concentration of wealth. The Act attempted to curb monopolistic, restrictive, and unfair trade practices. This Act complemented the license Raj.

Since December 1991 introduction of economic reform, liberalization policy in the era of globalization, the license Raj was abolished and consequently the MRTP, into the FEMA. The Indian economy was now its way to becoming a market friendly economy, crony capitalism. This encouraged unbridled competition, and therefore, a need was to regulate the economy, and the Competition Act, 2002, focuses on industry structure, and permits existence of 'dominant firms' as long as this dominance is not exploited by the firms in the market place. As per the law, any form of 'collusion' is prohibited because it either eliminates or reduces competition.

If we consider, a situation where a monopoly is being broken to foster competition the result will be transfer of income from producers to consumers and we would alleviate the 'dead weight losses'. Hence, introduction of competitive market is to generate the outcomes of competitive markets and pass these benefits to consumers in the form of lower prices.

As per the chronological status of development of market structures, perfect competitive 
market is surviving in most of the developing economies, and their industrial sector and services are getting aligned with monopolistic competitive markets, where monopolist might suck the consumers welfare, and brands it his/her own profit with a help of varieties of market mechanism. It has following characteristics:

a) The market has a large number of sellers of a product, and large number of buyers in the market. They have sufficient knowledge about the product to be purchased and numbers of opinions available to choose from.

b) Product differentiation. It creates brand loyalty of the consumers, and gives rise to a negatively sloping demand curve, and finally, provides the rationale selling expenses. Product changes, advertising and salesmanship are the main means of product differentiation.

c) Even so, with product differentiation there is no such thing as a unique price. Product differentiation allows each firm to charge a different price.

d) There will be no unique equilibrium price, but an equilibrium cluster of prices, reflecting the preferences of consumers for the products of the various firms in the group.

e) Social welfare and monopolistic competitive market both works diametrically opposite.

Monopolistic competition suffers from the fact that the price is higher than the marginal cost (MC). Socially output should be increased until price equals MC. However, this is impossible since all firms would have to produce at a loss in the long run the LMC long run marginal cost) intersects the DD curve (demand curve) below the LAC (long run average cost) (Fig. no.2). Thus any policy at the equalization of $\mathrm{P}$ (price of the given commodity) and MC would imply a loss of $a b$ per unit of output in the long run. In such a situation if firms were coerced to produce a level of output at which $\mathrm{P}=\mathrm{MC}$, the firm would close down in the long run.

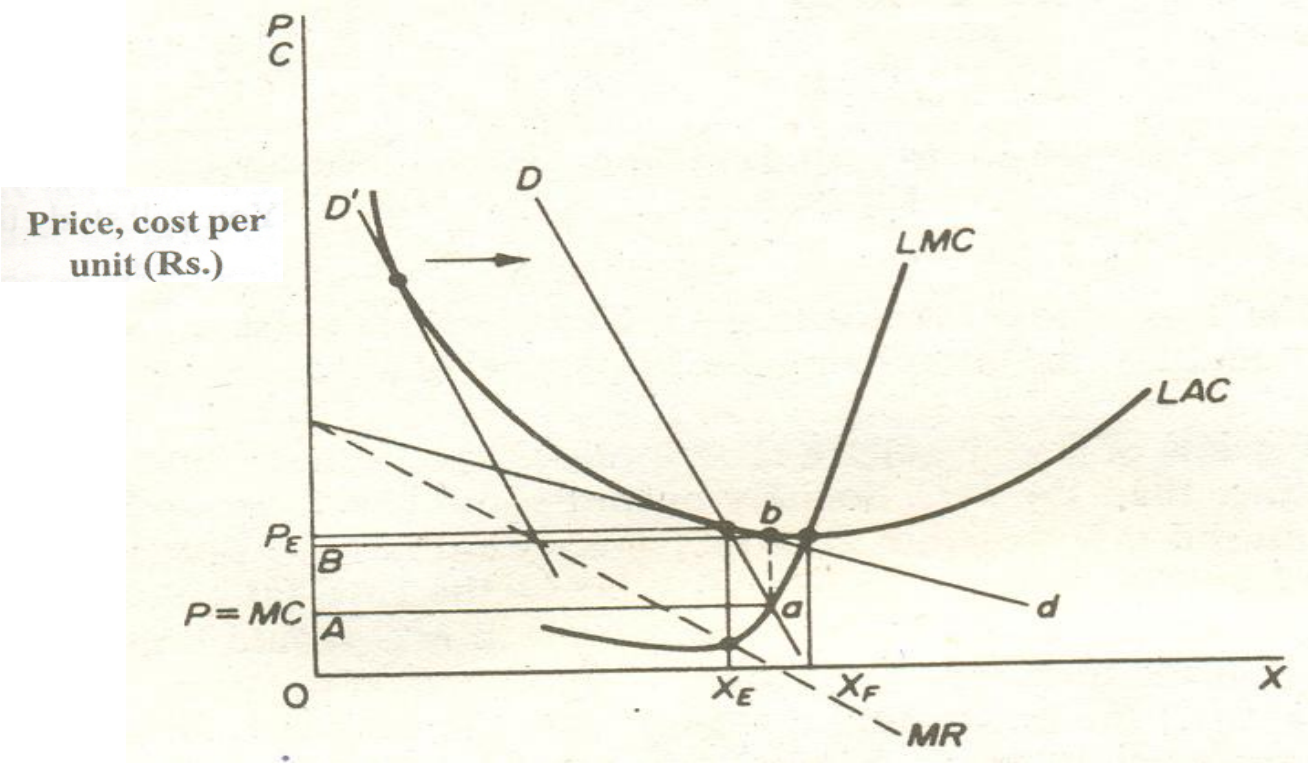

Fig. 2: Price Competition and Social Optimum in monopolistic competitive market (Source: fig. 8.6, pp.213, Modern Microeconomics (second edition) by A. Koutsoyiannis ${ }^{1}$, ELBS/ Macmillan edition first published 1985.) 
Hence, if the market is monopolistically competitive the output lower than the society would 'ideally' like it to be (i.e. price is higher than MC).

Kotler (2003) argues price differentiation, product differentiation, and price competition, is the main feature of global marketing system, is nothing, but it is his to say that 'monopolistic competitive market is the best regulatory mechanism in the epoch of globalization'. Hence, it is logical support to the characteristic features of monopolistic competitive market as 'there will be no unique equilibrium price, but an equilibrium cluster of prices, reflecting the preferences of consumers for the products of the various firms in the group'.

Consequently, 'Jago Grahak Jago' 'consumer might do bargaining at MRP (maximum retail price)' as it is propagated by various radio channels, is nothing but a justification of monopolistic competitive feature of market system, where social welfare is being crushed down by market forces. It is a discontent of Globalization also.

\section{Part II: Varieties of E-Databases and Users}

Modern globalization, and liberalization and privatization of economy, fast economic growth of business and industries, and improved information and communication technology (ICT) applications in business have multi-fold effects on the information industries in India.

\section{Marketing of e-products/databases}

Marketing is the process of planning and executing the conception, pricing, promotion and distribution of goods, services and ideas to create exchange that satisfy individual and organizational objectives. While e-marketing is to use technology such as internet as a communications and distribution channel, and email the Web including its wide variety of options and tools to conduct marketing activities that reduce time and responses become faster to marketers and end users, increased ability to collect and measure data, opened possibilities to personalized marketing, increased interactivity, and audience size. In the digital age information and knowledge flow become even faster, and users would like to be able to find everything that they need in digital form.

\section{Marketing Strategies in digital era}

Marketing management lies heavily on designing the organization's offerings in terms of the target markets' needs and desires, and on using effective pricing, communication, distribution to inform, motivate, and servicing the markets. The concept of marketing, e-marketing and database marketing in libraries and information centers is gaining momentum.

Local Area Network (LAN) is used in different types of libraries. Academic libraries for example often operate with split sites and multi-storied buildings. Here LANs are used to support sharing of disc storage and other expensive central facilities such as printers. LAN is a means of making of workstation for an OPAC (On-line Public Access Catalogue) available in a variety of different location, public libraries are widely scattered. Special libraries and other information managers are likely to have the opportunity to exploit LAN that covers the whole organization. LAN is used as more users friendly, which offers a wider variety of services. 
Videotext provides information to the users; it is divided into two main categories as community information and bibliographic information. Tele-text is a non-interactive form of videotext and as such is a system designed for the general public and mass communication. Libraries use the E-mail to investigate the potential of this facility. As libraries install computer network, between their various points electronic mail and software could assist in the exchange of or access to management information.

\section{Part III: E-Databases Prices in the State of Delhi}

This part is based upon primary data about marketing and price rise of e-databases in the state of Delhi. A primary data collection survey was conducted during November 15 to December 07, 2008. The questionnaire consists two parts: for users and the library information professionals (LIPs) included Library executives, library in charges, library information providers and technical experts of library information and e-databases as well as senior library workers in the State of Delhi. Total number of users were contacted are 459 and 115 LIPs from 23 libraries and 10 information centers in the State of Delhi.

This part is divided into two sub parts: a) Estimation of price rise during 2006-2008, and b) types of journals are being accessed by users, their grievances about rising subscription, individual estimates of LIPs about price rise of e-databases in the State of Delhi.

\section{a) Estimation of Price-Rise during 2006-2008}

As we have realized that e-databases products entertain monopolistic competitive market structure and users are sufferers of differential and more and more cluster price mechanism. Users and LIPs have been realized that e-databases charges are going to increase and more and more users have become fatigue. Sometimes they feel relief when they entertain highly equipped library facility with less fee charges or free of cost. In such a situation they appreciate the library management and institutional capacity for maintaining such types of e-databases and providing facilities to entertain them. Simultaneously, the highly equipped library executives and caretakers will be last their courage and potential to provide information services to outside or occasional users at the very low fee structure or free of cost in near future. Why are users and LIPs worried? What is the main reason behind it? It is a fact that both users and LIPs are two side of a coin, i.e. information system and knowledge economy.

Users are worried for getting relief from rising prices of e-databases, while LIPs with rising subscription of e-databases like e-books, e-journals, LAN, OPAC and other information facilitating software. In the era of globalization, there are numbers of pricing mechanisms/ pricing strategies are being applied by conglomerates and consortia of e-databases developers and publishers, computer technology providers. In nutshell, it is assumed that rising subscription of e-databases a reason behind fatigues of both users and LIPs.

The table no.4 is the estimation for price-rise of e-databases in the State of Delhi. It is based on the list of prices for year 2006, 2007, and 2008. The list of prices of the two publishers and e-databases providers, Cambridge University Press and Springer-Verlag, and it contains of of 25 titles of e-Journals, and software. Cambridge University Press Journals are priced with 
three types of pricing strategies: Print, bundle and e-only price, and Springer Verlag are that of two types: Print including free access/ e-only price (Euro) and Print including enhanced access price (Euro). First, it is estimated percentage rise in prices of the three pricing and two pricing based value respectively for the year 2007 and 2008. The list price for 2006 is assumed as the base year for two years: 2007 and 2008. Price rise is calculated for each pricing strategy based price separately, and then is taken arithmetic average of the three and the two prices respectively. Then it is calculated Geometric mean (GM) of the estimated two-year: $2007 \& 2008$ price indexes. Finally it is estimated the price rise of e-databases during $2006-2008$, which is shown in the given table no. 1.

This estimate is like a drop of an ocean of aura of monopolistic competitive market. This estimate holds very symbolic indicators of price rise of e-databases in the State of Delhi. < $20 \%$ price rise is seen in context of $80 \%$ e-databases, $20-30 \%$ in reference to $16 \%$ databases, and $>40 \%$ prices of $4 \%$ databases have risen up during 2006 to 2008 . 
Table No.: 1: Price- Rise of Databases from March 2006 to November 2008

\begin{tabular}{|l|l|l|}
\hline Name of the Databases & $\begin{array}{l}\text { Estimated Average Price Rise } \\
\text { during the year 2006 -2008 } \\
\text { (base Year 2006=100.0) }\end{array}$ & $\begin{array}{l}\text { Average Price } \\
\text { Rise } \%\end{array}$ \\
\hline Environment and Development Economics & 110.9 & $10.9^{1}$ \\
\hline European Journal of Applied Mathematics & 117.9 & $17.9^{1}$ \\
\hline Genetical Research & 121.5 & 21.5 \\
\hline Geological Magazine & 115.5 & $15.5^{1}$ \\
\hline Journal of Agricultural Science & 111.5 & $11.5^{1}$ \\
\hline Journal of Fluid Mechanics & 123.1 & $23.1^{2}$ \\
\hline Journal of Plasma Physics & 120.5 & $20.5^{2}$ \\
\hline Macroeconomics Dynamics & 127.1 & $27.1^{2}$ \\
\hline Parasitology & 125.4 & $25.4^{2}$ \\
\hline World Trade Review & 115.3 & $15.3^{1}$ \\
\hline Adsorption & 103.2 & $03.2^{1}$ \\
\hline Chemical and Petroleum Engineering & 111.9 & $11.9^{1}$ \\
\hline Climatic Change & 114.5 & $14.5^{1}$ \\
\hline Differential Equations & 111.0 & $11.0^{1}$ \\
\hline Ecological Research & 116.3 & $16.3^{1}$ \\
\hline Environmentalist & 109.4 & $09.4^{1}$ \\
\hline European Physical Journal C-Particles and Fields & 103.1 & $03.1^{1}$ \\
\hline Heat and Mass Transfer & 114.9 & $14.9^{1}$ \\
\hline Journal of Economics & 112.6 & $12.6^{1}$ \\
\hline Journal of Experimental and Theoretical Physics & 111.0 & $11.0^{1}$ \\
\hline Journal of Mathematical Sciences & 111.9 & $11.9^{1}$ \\
\hline Microbiology & 111.0 & $11.0^{1}$ \\
\hline Plant Molecular Biology & 110.6 & $10.6^{1}$ \\
\hline Water Resources & 110.9 & $10.9^{1}$ \\
\hline Water Resources Management & 143.5 & $43.5^{4}$ \\
\hline Average of total given databases & 115.4 & $15.4^{1}$ \\
\hline & & \\
\hline
\end{tabular}

Source: Price catalogue: 2006, 2007 and 2008. Cambridge University Press and Price catalogue: 2006, 2007 and 2008, Springer-Verlag. Note: 1: price rise $<20 \% ; 2: 20-30 \% ; 4:>40 \%$.

\section{b).Usage of e-databases and approaches of Users and LIPs}

This sub part is divided as follows: i) Types of Databases, ii) Impact of increasing subscriptions, iii) Queries about the e-Databases, iv) Types of pricing models, v) Price Rise of e-databases.

\section{b)-i) Types of Databases}

The State of Delhi's city Delhi-New Delhi has become one of the most developed high-tech city of the Indian Union. It has numbers of libraries and information centers 
of international repute. More than 100 types of e-databases oriented journals, magazines, news papers, e-books are read and visited by varieties of users and professionals daily at different knowledge facilitating centers in the State of Delhi. A few of them are Prowess online Database (6), Middle East Economic Survey Online (5), EDSCO (Natural Science)(7), Oxford University Press Consortium (12), Web of Science Database, SAS (State Analysis Service), List of Online Magazines(47), FAO STAT: Site License (3), Social Science Research Network (Online Database), Bibliographical Databases, CAPITALINE, etc.

Our spotted users follow e-databases of 13 titles. Out of total users 17 percent are regular visitor of ScienceDirect journal database, NIC databases (13.3 percent), Business databases (10.7 percent), IndiaStats.Com database (9.8 percent), Other Government databases ( 7.8 percent), JSTOR ( 7 percent), CMIE databases ( 6.8 percent), SpringerLink journal databases (6.3 percent), Lexis-Nexis (5.4 percent), Scopus (4.1 percent), Infraline databases (3.7 percent), and Mathscinet (2.8 percent) (table no.: 2). Most of the e-databases users are science orientation, and most of them preferred e-databases listed prices are in Euro/ $£ / \$$ currency. These currencies are very skeptical nature in terms of their absolute value and exchange value either, which may cause to face resource crunch to the establishments or Libraries and information centres in the State.

Table no. 2: Types of Database are used by users

\begin{tabular}{|l|l|r|r|}
\hline Sl. No. & Types of Database & No of Users & \% of Total Users \\
\hline 1. & ScienceDirect journal database & 78 & 17.0 \\
\hline 2. & NIC databases & 61 & 13.3 \\
\hline 3. & Business databases & 49 & 10.7 \\
\hline 4. & IndiaStats.Com database & 45 & 9.8 \\
\hline 5. & Other Government databases & 36 & 7.8 \\
\hline 6. & JSTOR & 32 & 7.0 \\
\hline 7. & CMIE databases & 31 & 6.8 \\
\hline 8. & SpringerLink journal databases & 29 & 6.3 \\
\hline 9. & Lexis-Nexis & 25 & 5.4 \\
\hline 10. & Emeraldinsight & 24 & 5.2 \\
\hline 11. & Scopus & 19 & 4.1 \\
\hline 12. & Infraline databases & 17 & 3.7 \\
\hline 13. & Mathscinet & 13 & 2.8 \\
\hline 14. & Total & 459 & 100.0 \\
\hline
\end{tabular}




\section{b)-ii) Impact of Increasing Subscriptions:}

Information is an intangible product for marketing system of economy. It has two facets of exchange system of economy as well. One is uses, and prices the next one. Uses of information are used by users to convert it into knowledge, while its prices facilitate profit and maximum profit earning opportunity to its packaging agents/ publishers/ marketers. Marketers have orientations of maximizing profit from the information products. As we have seen that age of globalization is the manifestation of monopolistic competitive market structure. In the State of Delhi libraries and information centers are the e-databases facilitators to the intellectuals, learners, professional, i.e., users also have become a part and parcel of globalized world.

In such a situation major chunk of users are distressed to rising subscription of e-databases. According to table no. 3, out of total users of 37.7 percent are satisfied with rising subscription of e-databases only. Simultaneously, 25.9 users are unsatisfied, and 26.6 percent users expressed that 'Increasing subscription is Extra load upon Users (ISELUs)'. About 10 percent users responded as 'can't say'. (Figure no. 3). In terms of well versed and well aware users, above the 58 percent are alienated from the rising subscription of e-databases in the State of Delhi.

Table No. 3: Relevance of increasing subscription to database and users' satisfaction

\begin{tabular}{|l|l|r|r|c|}
\hline S1. No. & $\begin{array}{l}\text { Types of Acceptances upon increasing } \\
\text { subscription rate }\end{array}$ & No. of Users & \% of total Users & Cumulative \% \\
\hline 1. & Satisfied & 173 & 37.7 & 37.7 \\
\hline 2. & Unsatisfied & 119 & 25.9 & 63.6 \\
\hline 3. & Can't Say & 45 & 9.8 & 73.4 \\
\hline 4. & Increasing subscription is Extra load & 122 & 26.6 & 100 \\
\hline & upon Users (ISELUs) & 459 & 100.0 & 100.0 \\
\hline
\end{tabular}




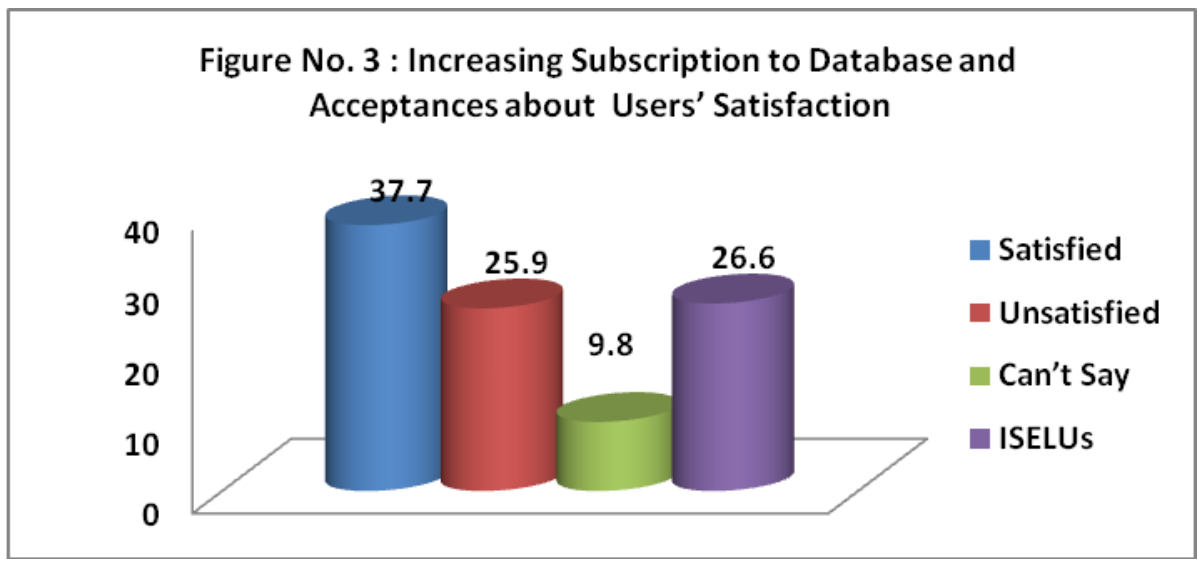

\section{b)-iii) Queries about the e-Databases}

Knowledge economy is increasing day by day, and the role of computer technology of its development is precious. Users are very keen in increasing their information level with a help of e-databases. They are eager to get to know about the types of databases, which would be available in libraries and at information centres in order to satisfy their queries. Out of total respondents 65 percent users made queries about research articles and papers, Specific information on subjects (42.5 percent), news papers (39.4 percent), Value added information analysis (24.8 percent), Statistical information (19.0), study materials (15.5 percent), books (14.6 percent), and Audio -Vedio documents (11.5 percent) (table no. 4). It is obvious that majority of users made queries upon two and more subjects of their interests.

Table No. 4: Users' Queries about Databases Information at the library

\begin{tabular}{|l|l|l|c|}
\hline Sl. No. & Varieties of Information & No. of Users & \% of Total \\
\hline 1. & Research Articles /Papers & 298 & 64.9 \\
\hline 2. & Specific information on subjects & 195 & 42.5 \\
\hline 3. & News Papers & 181 & 39.4 \\
\hline 4. & Value added information analysis & 114 & 24.8 \\
\hline 5. & Statistical information & 87 & 19.0 \\
\hline 6. & Study Material & 71 & 15.5 \\
\hline 7. & Books & 67 & 11.5 \\
\hline 8. & Audio -Vedio documents & 53 & 14.6 \\
\hline
\end{tabular}




\section{MlMacrothink}

\section{b)-iv) Types of Pricing Models}

Most of companies/consortia engaged in information products marketing are international marketers/ producers/MNCs/ world leaders of information products. Pricing strategies work through the various pricing models. Pricing models are the crux of marketing mantras, and heart-beat of the 4 Ps of marketing (product, place, promotion, and price). "The goal of marketing is usually to maximize profit and not necessarily sales and demand. -Marketing can alleviate the supply problem by manipulating the components---and can be adjusted (e.g., less advertizing, more selective distribution, higher price) so as to bring demand down to a level more closely maintaining supply.- - the marketing process stimulates innovations, which provide new and better ways to satisfy consumer needs more efficiently and effectively"(Sak Onkvisit and John J. Shaw, $2007)^{8}$.

There are numbers of pricing models are running in the information and e-databases based market in the State of Delhi. Types of pricing are identified by libraries and information professionals (LIPs). According to table no. 5, out of total 58.3 percent respondents recognized the list/catalog pricing (MRP)+ discount model, consortia based pricing (37.4 percent), customized pricing (32.2 percent), e-only pricing :deep discount pricing (25.2 percent), bundle pricing (18.3 percent), and user population based pricing identified by 13 percent LIPs only. Thus, 'list/catalog pricing (MRP) + discount' is the more popular pricing model, and 'user population based pricing model' is least pronounced amongst LIPs in the State of Delhi. "Discounts (cash, quantity, functional, and so on) can be used to adjust prices indirectly" (Sak Onkvisit and John J. Shaw, 2007) ${ }^{8}$.

Table No. 5: Type of Pricing Models of Databases Running in the State of Delhi

\begin{tabular}{|c|l|c|r|}
\hline Sl. No. & Types of Pricing & $\begin{array}{l}\text { Accepted by } \\
\text { LIPs }\end{array}$ & $\begin{array}{l}\text { \% of Total } \\
\text { LIPs }\end{array}$ \\
\hline 1. & List/Catalog pricing (MRP)+ discount & 67 & 58.3 \\
\hline $\mathbf{2 .}$ & Consortia based pricing & 43 & 37.4 \\
\hline 3. & Customized pricing & 37 & 32.2 \\
\hline 4. & e-only pricing (Deep discount pricing) & 29 & 25.2 \\
\hline 5. & Bundle Pricing. & 21 & 18.3 \\
\hline 6. & User population based pricing & 15 & 13.0 \\
\hline
\end{tabular}




\section{MlMacrothink}

\section{v) Price Rise of e-databases:}

Price should never be treated as an isolated factor - consumers around the world do not mind a high price if they indeed, "get what they pay for." (Sak Onkvisit and John J. Shaw, 2007, pp. 606). In general, price rise is treated as mounting inflationary pressures on the products. But process of monopolistic competitive price-rise has its own characteristic feature that is to make more and more profit. LIPs observed that subscription rate of e-databases compel to think and find out some amicable solution about. They become fatigue after mapping the effects of price rise on their library system and information centres. More than 95 percent of total respondents (LIPs) were crystal clear about the effects of price-rise and they feel standstill in order to deal with it (Table no.6).

Table No. 6: Price Rise of e-Databases: 2006- Nov. 2008

\begin{tabular}{|c|l|l|}
\hline List Price Rising & Accepted by LIPs & Cumulative Responses (\%) \\
\hline$<20$ & 78 & 67.8 \\
\hline $20-30$ & 24 & 88.7 \\
\hline $30-40$ & 11 & 98.3 \\
\hline$>40$ & 2 & 100.0 \\
\hline Total & 115 & 100.0 \\
\hline
\end{tabular}

Profit and maximization is like life saving drugs for business concerns and marketers. Now the phrase:' price is right' has become very popular amongst richest consumers and global players/intermediaries and joint ventures of marketing mix globally. In case of the State of Delhi, users are becoming fatigue to price rise of e-databases in their usual talks. LIPs are becoming apprehensive to look into the rising subscription of e-databases. Out of total respondents 67.8 percent LIPs thought that subscription rate of e-databases had been increased below 20 percent during 2006-2008, while 20.9 percent realized that it would be up to 20-30 percent and 9.6 percent was very shocked to price rise and they said it must be 30-40 percent. Finally, 1.7 percent LIPs was very afraid with rising subscription of e-databases and they thought that it might be escalated to above the 40 percent between 2006 and 2008. (Figure no. 4). 


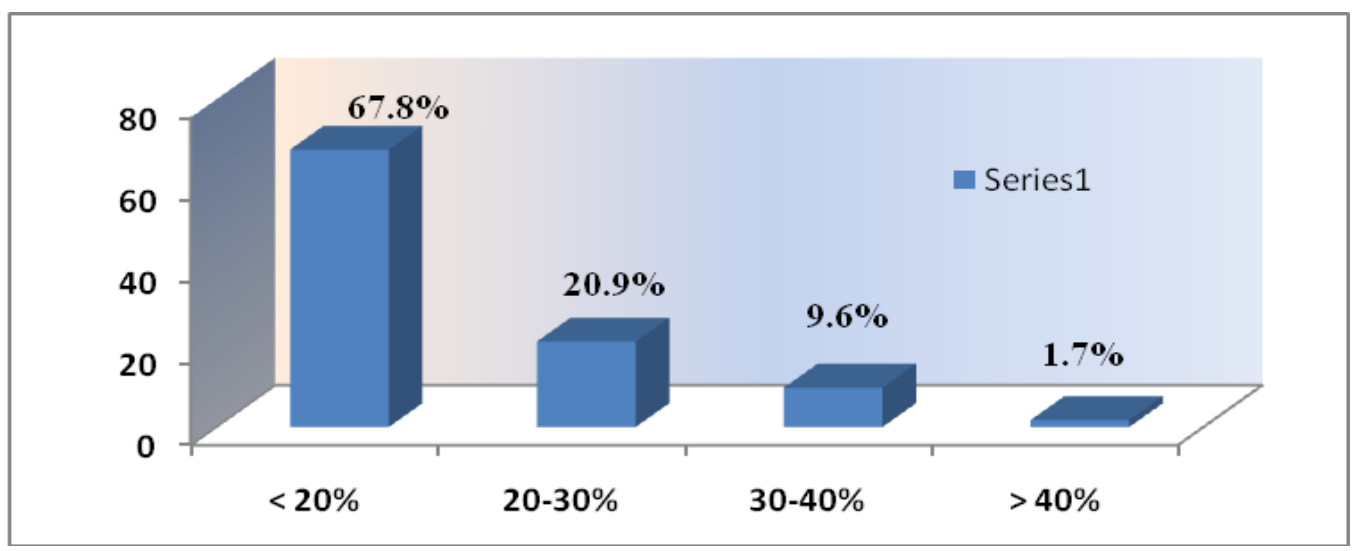

Figure No. 4: Price Rise of Databases in Delhi

\section{Part IV}

\section{Findings:}

There are two types if findings, i.e., objective and subjective findings.

\section{Objective findings:}

i) According to estimated price-rise, 96 percent of e-databases prices have risen up to 30 percent between 2006 and 2008. Subscription prices of 4 percent databases have crossed even the boundary of 40 percent price-rise.

ii) More than 100 types of e-databases oriented journals, Magazines, News papers, e-books are read out and visited by varieties of users and professionals daily at numbers of libraries and knowledge facilitating centers in the State of Delhi.

iii) The era of globalization is the manifestation of monopolistic competitive market structure.

iv) Out of total 37.7 percent users are satisfied with rising subscription of e-databases only. Above half of the users are scared with price-risen up exercises of publishers/providers of e-databases and unsatisfied as well as they assumed 'Increasing subscription is Extra load upon Users (ISELUS)'.

v) 'List/catalog pricing (MRP) + discount' is the more popular pricing model, and 'user population based pricing model' is least pronounced amongst LIPs in the State of Delhi.

vi) More than 95 percent of total LIPs feel standstill in order to deal with the problem of rising subscription rate of e-databases.

vii) Out of total respondents 87.7 percent LIPs thought that subscription rate of e-databases might have been increased up to 20-30 percent and 9.6 percent was apprehensive to 30-40 percent risen up of subscription rate between 2006 and 2008.

viii) Users as well as LIPs are apprehensive about increasing threats in terms of rising subscription of conglomerates of e-databases in the state of Delhi.

\section{Subjective Findings:}

i) The monopolistic market categorically offers differentiated products, though the difference in product is marginal. There will be no unique equilibrium price, but an equilibrium cluster 


\section{Macrothink}

Enterprise Risk Management

ISSN 1937-7916

2009, Vol. 1, No. 2: E4

of prices, reflecting the preferences of consumers for the products of the various firms in the group.

ii) 'Jago Grahak Jago' 'consumer might do bargaining at MRP (maximum retail price)' which is run by FM channel, is nothing but a justification of monopolistic competitive feature of market system, where social welfare is being crushed down by market forces and major chunk of consumer surplus is transferred as profit of a monopolist .

iii) Effective promotion of marketing requires the process of persuasion that would be receiver (users) oriented, and he (user) reacts favorably. The message must gain control of the receiver's behavior at the right place and time.

iv) The time has been changed; marketers might not be able to manage their sales in terms of high price and low volume oriented goods in the era of global marketing system.

v) The library should be recognized as an information market, and the user is consumer of information. Information is time sensitive and time framed information becomes knowledge; otherwise, it turns into wastes.

\section{References:}

1. Koutsoyiannis A. (1985). Modern Economics, Second Edition, ELBS/Macmillan Publishers Ltd, Londin, PP. 213

2. WIPO draft treaty on intellectual property in respect of databases, http://www.wipo.org accessed on January 13, 2008.

3. Kotler P. (2003). Marketing management. $11^{\text {th }}$ edition. Singapore: Pearson Education Pvt. Ltd, pp.836.

4. Levitt T. (1983). The marketing imagination. New York, USA, The Free Press, pp 238.

5. http://www.quickmba.com/marketing/product/lifecycle/

6. Outsell Inc, USA report "Library Market Size, Share \& Forecast Report", 2008.

7. Hawkins D. T. (1981). In search of ideal information pricing. In Blaise Cronin (Editor), The marketing of library and information services. London: Aslib Occasional Publications. pp. 298-359.

8. Sak Onkvisit and John J. Shaw (2007). International Marketing: Analysis and Strategy, Third Edition, Prentice Hall of India, Pvt. Ltd., New Delhi. 